\title{
Description of three new species of Geometridae (Lepidoptera) using species delimitation in an integrative taxonomy approach for a cryptic species complex
}

\author{
Simeão Moraes ${ }^{\text {Corresp., } 1}$, Ygor Montebello ${ }^{1}$, Mariana A Stanton ${ }^{2}$, Lydia Fumiko Yamaguchi ${ }^{2}$, Massuo Kato $^{2}$, André V \\ L Freitas ${ }^{1}$ \\ ${ }^{1}$ Departamento de Biologia Animal and Museu da Biodiversidade, Universidade Estadual de Campinas, Campinas, São Paulo, Brazil \\ 2 Laboratório de Química de Produtos Naturais, Instituto de Química, Universidade de São Paulo, São Paulo, São Paulo, Brazil \\ Corresponding Author: Simeão Moraes \\ Email address: simeao_moraes@yahoo.com.br
}

The genus Eois Hübner (Geometridae: Larentiinae) comprises 254 valid species, 217 of which were described from the Neotropics and 31 of those having their type locality in Brazil. Since this species rich genus has never been revised, and may potentially include many cryptic undescribed species, Eois embodies a problematic taxonomic scenario. The actual diversity of Eois is greatly underestimated and the Brazilian fauna is poorly known, both because of inadequate sampling and because of the potential existence of cryptic species "hidden" within some nominal taxa. In this study we investigated the diversity within a cryptic species complexes associated do the E. pallidicosta and E. odatis clades. We describe three new species Eois oya Moraes \& Montebello sp. nov., Eois ewa Moraes \& Stanton sp. nov., and Eois oxum Moraes \& Freitas sp. nov., in an integrative taxonomy approach, using morphology, host plant use and species delimitation tools. 
2 Description of three new species of Geometridae (Lepidoptera) using species

3 delimitation in an integrative taxonomy approach for a cryptic species

4 complex

7 Simeão de Souza Moraes ${ }^{1 *}$, Ygor Zanelato Montebello ${ }^{1}$, Mariana Alves Stanton ${ }^{2}$, Lydia Fumiko 8 Yamaguchi $^{2}$, Massuo Jorge Kato ${ }^{2}$, André Victor Lucci Freitas ${ }^{1}$

${ }^{1}$ Departamento de Biologia Animal and Museu da Biodiversidade, Universidade Estadual de Campinas, Campinas, São Paulo, Brazil

$12{ }^{2}$ Laboratório de Química de Produtos Naturais, Instituto de Química, Universidade de São

13 Paulo, São Paulo, São Paulo, Brazil

*Corresponding author:

Simeão Moraes

Email address:simeao_moraes@yahoo.com.br

20

21

22

23

24

25

26

27

28

29

30

31

32

33

34 
Abstract which were described from the Neotropics and 31 of those having their type locality in Brazil. Since this species rich genus has never been revised, and may potentially include many cryptic undescribed species, Eois embodies a problematic taxonomic scenario. The actual diversity of Eois is greatly underestimated and the Brazilian fauna is poorly known, both because of

44 inadequate sampling and because of the potential existence of cryptic species "hidden" within some nominal taxa. In this study we investigated the diversity within a cryptic species complexes associated do the E. pallidicosta and E. odatis clades. We describe three new species Eois oya Moraes \& Montebello sp. nov., Eois ewa Moraes \& Stanton sp. nov., and Eois oxum Moraes \& Freitas sp. nov., in an integrative taxonomy approach, using morphology, host plant use and species delimitation tools.

Keywords: host-plant, morphology, Eois, dna-barcode

\section{Introduction}

Geometridae is a megadiverse family with over 24000 species, being the most species

54 rich lineage in the superfamily Geometroidea and the second most species-rich family among

55 Macroheterocera lineages (Scoble 1999, Sihvonen et al. 2011, Mitter et al. 2017). The family

56 Geometridae represents a challenge for researchers because of the taxonomic uncertainties

57 around some species rich genera, for which taxonomic reviews are lacking and several new taxa 58 await formal descriptions (Strutzenberger et al. 2011, 2012). Despite the existence of a 
59 worldwide catalog (Scoble 1999), only a small subset of Geometridae genera has been revised

60 (Hulst 1896, Wehrli 1939-1954, Rindge 1990, Pitkin 2002). Most of these taxonomic studies are

61 restricted to specific geographic areas, leaving the Neotropics as one of the least studied

62 biogeographic regions for the Geometridae fauna.

Eois Hübner belongs to the subfamily Larentiinae and is one of the most species-rich

64 genus, with 254 described species (Brehm et al. 2011), 217 of which were described for the

65 Neotropical region and 31 primary types for Brazil. Species of Eois are small, reaching up to 2

$66 \mathrm{~cm}$ in wingspan, and most species present a wing pattern consisting of a yellowish or brown

67 background patterned with reddish or rusty symmetrical bands on both wings. Based on a study

68 with some species from Borneo (Holloway 1997), the male genitalia lack the uncus and labides,

69 while female genitalia present a robust bursa with multiseriate signa. Recently, Brehm et al.

70 (2011) showed that characters from valvae and vesica on the male genitalia might be

71 phylogenetically informative and also useful in delimiting species.

Notwithstanding Eois being recognized as an important component of the diversity of

73 neotropical moths (Brehm et al. 2011), there is still a large gap in the knowledge and

74 representativeness of the Brazilian fauna. Single-locus species delimitation methods were

75 recognized as a useful approach when working with montane Eois species (Strutzenberger et al.

76 2011) and recently this diversity was also increased for lowland species (Moraes et al.

77 submitted). However, despite the use of molecular methods for species-delimitation having

78 proven to be extremely valuable in highlighting cryptic diversity, fewer than $30 \%$ of the studies

79 on species delimitation made taxonomic recommendations and only $25 \%$ described new species

80 (Carstens et al. 2013). 
In the present study we contribute to the knowledge of the Eois diversity using an

82 integrative taxonomic approach on cryptic species complexes, and describe three new species of

83 Eois. Accordingly, we accessed the molecular diversity and used the Automatic Barcode Gap

84 Discovery method (ABGD) for species delimitation (Puillandre et al. 2012). To test the validity

85 of the molecular taxonomic units (MOTUs) we studied morphological characters for wing

86 pattern and genitalia, as well as host plant use by larvae. We expect that these practices will

87 improve the number of new taxa described in cryptic complexes, increasing the knowledge on

88 the real diversity of Eois from Brazil.

89

\section{Material and Methods}

$91 \quad$ Sampling

92 Immature stages and imagos of Eois were obtained from six localities: i) Serra do Japi

93 Biological Reserve (23 14’ S 46 58' W), Jundiaí, São Paulo, Brazil; ii) Boraceia Biological

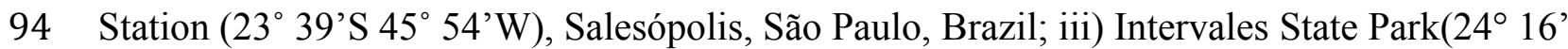

95 S $48^{\circ} 24^{\prime}$ W), Ribeirão Grande, São Paulo, Brazil, iv) Itatiaia National Park (22 $27^{\prime}$ S 44 37'

96 W), Itatiaia, Rio de Janeiro, Brazil, v) Serra dos Orgãos National Park (22²7’ S 42 59’ W),

97 Teresópolis, Rio de Janeiro, Brazil, and vi) Adolpho Ducke Forest Reserve (2॰ $57^{\prime} \mathrm{S} 59^{\circ} 55^{\prime}$

98 W), Manaus, Amazonas, Brazil.

99 Imagos were collected during the night using a light source consisting of a a 500W mix

100 bulb on a square white sheet ( $2 \mathrm{~m}$ side). Immatures were collected by searching plants of the

101 genus Piper L. and Peperomia Ruiz \& Pav.(Piperaceae), known larval host plants of several

102 species of Eois, and were reared in the laboratory. Samples of the host plant, including leaves,

103 inflorescence and fruits, were also collected for further identification. Permits for field trips were 
104 issued by Instituto Chico Mendes de Conservação da Biodiversidade (ICMBio, permit nos.

105 10362-1, 15780-10 and 22205-6). All new described species are registered in the SISGEN 106 (A4ED092).

107

108

Rearing methods

109

Larvae were reared in individual $300 \mathrm{~mL}$ clear plastic vials with lids, and provided with leaves of the same Piper and Peperomia plants on which they were collected (Moraes et al.

111 2016). Pupae were transferred to individual $50 \mathrm{~mL}$ clear plastic vials with lids and moist cotton

112 wool until emergence. Larvae and pupae were maintained under constant temperature $\left(25^{\circ} \mathrm{C}\right)$ and

$11312 \mathrm{~h}$ light: $12 \mathrm{~h}$ dark cycle. After emergence, imagos were sacrificed for DNA extraction and

114 genitalia dissection. Samples of the host plants were collected and compared to previously

115 identified samples from the same locality made at the Laboratório de Química de Produtos

116 Naturais, at the University of São Paulo, and compared to the species description in the Brazilian

117 Flora 2020 project (Guimarães et al. 2015).

118

119

DNA extraction and PCR conditions

Three legs were removed from each specimen shortly after collection and before

121 spreading. Sampled legs were preserved dry and stored in $1.5 \mathrm{ml}$ tubes at $-20^{\circ} \mathrm{C}$. Total genomic

122 DNA was extracted with DNeasy Blood \& Tissue Kit (Qiagen, Netherlands), according to the

123 manufacturers protocol with final elution in $100 \mu$ l elution buffer. The 5 ' end (barcode region) of

124 the mitochondrial gene cytochrome oxidase subunit I (COI, $650 \mathrm{bp}$ ) was amplified using the

125 primers $\mathrm{HCO}$ and LCO (Folmer et al. 1994) containing the T3 and T7 promotor universal tails,

126 respectively (Wahlberg \& Wheat 2008). Polymerase chain reactions (PCRs) were performed 
127 with $13 \mu$ l total volume containing 1-2 $\mu$ l of extracted DNA, 3.2-4.2 $\mu 1$ of $\mathrm{H}_{2} \mathrm{O}$ milli-Q, $6.5 \mu 1$ of

128 2x MyTaq HS red mix (Bioline Co., UK), and $0.65 \mu 1$ of each primer (10 mM). PCR products

129 were amplified as follows: $96^{\circ} \mathrm{C}$ for 7 minutes, followed by 40 cycles of $96^{\circ} \mathrm{C}$ for 30 seconds,

$13050^{\circ} \mathrm{C}$ for 30 seconds and $72^{\circ} \mathrm{C}$ for 90 seconds, and a final extension period of $72^{\circ} \mathrm{C}$ for 10

131 minutes.

$132 \quad$ Amplicons were purified adding a mix of $1.3 \mu 1$ of FastAP Thermosensitive Alkaline

133 Phosphatase (Thermofisher Scientific, USA) and $0.7 \mu 1$ of Exonuclease 1 (Thermofisher

134 Scientific, USA) to $10 \mu 1$ of PCR products. Purified products were sent for Sanger sequencing.

135

136

137

138

139

140

141

142

143

144

145

146

147

148

149

Alignment, tree inference and species delimitation

The genetic dataset consisted of 160 newly sequenced individuals of 18 putative species

combined with 36 sequences obtained from Genbank (Table 1). Sequences were aligned using

MAFFT (Katoh et al. 2002) implemented in Geneious v.11.0.2 (Kearse et al. 2012). The

alignments were carefully checked by eye, taking into consideration the reading frame relative to the reference sequence. The Maximum Likelihood analyses were conducted using RAxMLHPC2 V.8.2.10 (Stamatakis 2014) on the webserver CIPRES Science Gateway (Miller et al. 2010). Support for nodes was evaluated with 1000 ultrafast bootstrap (UFBoot2) approximations (Hoang et al. 2018), UFBoot2 values $\geq 95$ indicate well-supported clades

In order to study the species boundaries within our dataset, we used a species delimitation method focused on single-locus gene analysis: The Automatic Barcode Gap Discovery (ABGD, Puillandre et al. 2012). This method appeared to be more congruent with the Eois morphology compared to other methods (mPTP and bPTP) (Moraes et al. submitted). The ABGD method seeks to quantify a range of the barcode gap that separates intra from interspecific distances, automatically clustering sequences into candidate species based on pairwise distances (Puillandre 
150 et al. 2012a). Default settings were used for the prior range for maximum intraspecific

151 divergence $(0.001,0.1)$. Results were compared using Jukes-Cantor (JC69) corrected distances

152 and relative gap width of 1.0. ABGD analyses were performed using the graphic web version.

153

154 Morphological study

155 The external morphology and color pattern were analyzed following the usual protocols

156 (Winter 2000). Wing venation and pattern were recorded and genitalia of females and males

157 were dissected. For interpretation and descriptions of genital structures we followed the

158 procedures outlined in Moraes \& Duarte (2009), based on classical studies on Lepidoptera

159 morphology (male genitalia in Pierce 1909, Sibatani et al. 1954, Okagaki et al. 1955, Klots 1956,

160 Ogata et al. 1957, Birket-Smith 1974; female genitalia in Pierce 1914, Klots 1956, Mutuura

161 1972, Galicia et al. 2008).

162 A total of 11 specimens belonging to the three new species here described were

163 examined. Characters of wing venation, color pattern, and male and female genitalia were

164 analyzed. The genitalia were illustrated with a camera lucida attached to a stereomicroscope.

165 Acronyms for the collections are: MZUSP - Museu de Zoologia da Universidade de São

166 Paulo, São Paulo, São Paulo, Brazil; ZUEC - Zoological Collection of the Museu da

167 Biodiversidade da Universidade Estadual de Campinas, Campinas, São Paulo, Brazil.

168 The electronic version of this article in Portable Document Format (PDF) will represent a

169 published work according to the International Commission on Zoological Nomenclature (ICZN),

170 and hence the new names contained in the electronic version are effectively published under that

171 Code from the electronic edition alone. This published work and the nomenclatural acts it

172 contains have been registered in ZooBank, the online registration system for the ICZN. The 
173 ZooBank LSIDs (Life Science Identifiers) can be resolved and the associated information viewed

174 through any standard web browser by appending the LSID to the prefix http://zoobank.org/. The

175 LSID for this publication is: urn:1sid:zoobank.org:pub:9450BCDC-7EB9-4CA6-BC76-

176 04324F81ACA4. The online version of this work is archived and available from the following

177 digital repositories: PeerJ, PubMed Central and CLOCKSS.

178 Results

179 Based on the present taxonomic sampling, the ML tree appeared divided into 10 main 180 clades named after representative species names in each clade (Fig. 1), following Strutzenberger 181 et al. (2017). From all defined MOTUs, three of them were identified as undescribed species

182 based on present molecular results and also on available morphological evidence, and are here

183 described. All but one species of Eois were reared on species of Piper and the host plant species 184 in which larvae of each MOTU were collected are shown, when available (Fig. 1). The ABGD 185 method used for delimiting species recovered each of new species here described as a distinct 186 molecular operational taxonomic units (MOTUs).

187 The first undescribed species was identified in the larger clade named "pallidicosta 188 clade" (after Eois pallidicosta (Warren, 1907)); the high UFBoot2 support values and the long 189 branch length (related to a genetic distance higher than $3 \%$ from all other species in the clade) 190 suggested that this is a distinct evolutionary lineage (Fig. 1).

191 The second undescribed species was identified in the "odatis clade" (named after Eois 192 odatis (Druce, 1892)). In this clade, one MOTU was recovered based on four specimens forming 193 a well supported clade that stands out by using Peperomia hispidula (Sw.) A.Dietr. (Piperaceae) 194 as larval host plant. 
197 in a high montane area in Southeastern Brazil. Despite having returned to the sampling site

198 several times no additional individuals were collected. Even though, its idiosyncratic wing

199 pattern and the morphology of genitalia justifies the description of this new taxa based only on

200 the holotype.

201

\section{Species Description}

203 Eois oya Moraes \& Montebello sp.nov. (Figs. 2A-B, 3)

Diagnosis ( $\varsigma^{\urcorner}$and 우). Forewing dorsal view with a horizontal black stripe on the trunk of

$205 \mathrm{Cu}$ vein, from the base of wing reaching the outer margin. Forewing and hindwing with a black dot on the discal cell closure. Aedeagus with a pointed spine close to vesica, vesica bilobed with spiniform cornuti (Fig. 3D).

Description ( $\varsigma^{\urcorner}$) (Figs 2A-B). Head: Light brown. Frons light brown, vertex light brown. gold scales. Tegulae light brown. Forewing background light brown, darker proximally;

211 horizontal black stripe on the trunk of $\mathrm{Cu}$ vein, from the base of wing reaching the outer margin; one 212 black dot on the discal cell closure; two vertical, mirrored stripes beyond discal cell closure, from 213 costal margin to inner margin; submarginal band as a faint stripe; marginal band following the outer 214 margin contour; underside with the same dorsal pattern. Hindwing with the same forewing 215 pattern, except being lighter proximally and without the submarginal stripe. Abdomen. Dorsally 216 brown; ventrally light brown with two lateral dark brown stripes. Genitalia (Figs. 3A-D):

217 Tegumen triangular in dorsal view, with the anterior margin round. Uncus absent. Valva entitre, 
218 sub-elliptical; sacculus developed, consisting of an anterior projection with rounded apex.

219 Labides absent. Fultura inferior or juxta sclerotized, shaped like an inverted "U". Saccus with a

220 short anterior projection. Subscaphium smooth. Aedeagus rectilinear with a spine near the

221 vesica; ejaculatory bulb rounded, foramen lateral; vesica bilobed, lobes with dense sclerotized

222 spiniform cornuti.

223 Description (ㅇ) Head: Same as in the male except for the antenna less pectinated.

224 Thorax: Same as in the male. Abdomen: Same as in the male. Genitalia (Fig 3E): Seventh

225 sternite smooth; ostium membranous not fused with the seventh sternite; antrum short and

226 membranous, except for a sclerotized bracket-shaped support close to corpus bursae; ductus

227 bursae short and membranous; corpus bursae extending beyond the seventh sternite; signa

228 consisting of several microspicles and a falciform spine. Bulla seminallis arising from a ventral

229 pouch on the posterior portion of corpus bursae. Lamella antevaginalis and postvaginalis absent.

230 Etymology. The specific epithet, oya is the Brazilian name for the female orisha who

231 commands the winds, lightning and storms. In the native culture of the Yoruba people, orishas

232 represent spirits sent for the guidance of all creation and of humanity.

The Portuguese spelling comes from the Yoruba "Oya" which means "she tore". She is

234 the patron of the Niger River, known to the Yoruba as the Odo-Oya. The specific epithet is a

235 tribute to women and to Brazilian black culture. A noun in apposition.

236 Distribution. The few records for this species are from medium and low altitudes $(800 \mathrm{~m}$

237 to $1200 \mathrm{~m}$ a.s.1.) in the Serra do Mar and Serra da Mantiqueira mountain chains, in a narrow

238 region of the Atlantic Forest near the border between the states of São Paulo and Rio de Janeiro. 
240 reitzii plants at the Parque Nacional do Itatiaia, in the state of Rio de Janeiro and reared to adults

241 in laboratory (see Methods section).

242 Type series. HOLOTYPE ${ }^{\top}$, ex larva: BRAZIL: Rio de Janeiro: Itatiaia:, Parque

243 Nacional do Itatiaia 22 27' 01.5" S 44"37' 14.0” W, 1174m asl, 03-VIII-2016, Simeão M.,

244 Tamara A. \& Mariana S leg. Deposited in the Zoological Collection of the Museu da

245 Biodiversidade da Universidade Estadual de Campinas (ZUEC), Campinas, São Paulo, Brazil.

246 PARATYPES (all from Brazil): Rio de Janeiro: Itatiaia, $10^{\urcorner}$and 2 우, ex larva, Parque

247 Nacional do Itatiaia, 22 27' 01.5” S 44 37' 14.0” W, 1174 m asl, 03-VIII-2016, Simeão M.,

248 Tamara A. \& Mariana S. leg. (ZUEC). São Paulo: Salesópolis, $1 \sigma^{\nearrow}$, Estação Biológica de

249 Boraceia, 2339'S 45 54’W, 850m asl, 28-X/ 01-XI-2016, Simeão M., Tamara A. \& André T

250 leg. (MZUSP).

251

252 Eois ewa Moraes \& Stanton sp.nov. (Figs. 2C-D, 4)

253 Diagnosis ( $\sigma^{7}$ and 우). Forewing dorsal view with dark brown maculae on the outer margin.

254 Forewings and hindwings with two vertical mirrored bands on discal cell closure, continuous with 255 dorsally dark brown abdominal segments A5 and A6 (Fig. 2C).

256 Description ( $\sigma^{\urcorner}$) (Figs 2C-D). Head: Brown. Frons brown, vertex brown. Labial palp light

257 brown. Thorax: Predominantly light brown. Prothoracic collar with iridescent gold scales.

258 Tegulae light brown. Forewing background rusty brown; two sinuous black stripes on the wing

259 base, from de trunk of $\mathrm{R}$ vein, reaching the inner margin; two vertical mirrored bands on discal cell

260 closure, from the trunk of R4+R5 to inner margin; dark brown maculae on the outer margin, merged

261 with the discal bands in the region of discal cell closure; underside with the same dorsal pattern. 
262 Hindwing with the same forewing pattern, except with the light brown background and the outer

263 maculae replaced by three bands composed of brown spots. Abdomen: Dorsally brown; dark

264 brown central macula on abdominal tergites A1-A4, abdominal tergites A5-A6 dark brown;

265 ventrally light brown with patches of dark brown scales on the sternite A2-A8 margin. Genitalia

266 (Fig. 4A-D): Tegumen triangular in dorsal view, with the anterior margin round. Uncus absent.

267 Valva trapezoidal; sacculus developed, consisting of an anterior projection with rounded apex.

268 Labides absent. Transtila sclerotized, squared. Fultura inferior or juxta sclerotized, shaped like a

269 "U”. Saccus with a short anterior projection. Aedeagus rectilinear and smooth; ejaculatory bulb

270 rounded, foramen lateral; vesica bilobed, lobes with two patches of sclerotized spiniform cornuti.

271 Description (우). Head: Same as in the male except for the antenna less pectinated.

272 Thorax: Same as in the male. Abdomen: Same as in the male. Genitalia (Fig. 4E): Seventh

273 sternite smooth; ostium membranous not fused with the seventh sternite; antrum short and

274 membranous, except for a sclerotized ring close to corpus bursae; ductus bursae short and

275 membranous; corpus bursae with multiseriated signa, signa consisting of several microspicles

276 displaced at the anterior portion of corpus bursae. Accessory bag smooth. Lamella antevaginalis

277 and postvaginalis absent.

278 Etymology. The specific epithet, ewa comes from Yoruba "Yewá". In Brazil, ewa is

279 name for the female orisha and river deity from the Yewá river, located in the ancient Egbado

280 tribe (present-day city of Yewa). In the native culture of the Yoruba people, orishas represent

281 spirits sent for the guidance of all creation and of humanity.

282 Ewa represents the gift of divination and intuition. She also represents the mutations,

283 transformations and the perception of what is beautiful and what is ugly. The specific epithet is a

284 tribute to women and to Brazilian black culture. A noun in apposition. 

the host plant Peperomia hispidula in humid montane forests (altitude of $1100 \mathrm{~m}$ a.s.1.) at the

287 Itatiaia National Park, in the state of Rio de Janeiro.

Nacional do Itatiaia, 22 25'37.8” S 44 37' 07.0” W, 1100 m asl, 30-VI-2017, Lydia Y.,

Mariana S. \& Simeão M. leg. (ZUEC); 1 우, ex larva: 30-VI-2017, Lydia Y., Mariana S. \&

Simeão M. leg. (MZUSP).

Eois oxum Moraes \& Freitas sp.nov. (Figs. 2E-F, 5) dot on the center of discal cell. Abdominal segments A1 and A2 olive green dorsally (Fig. 2E) center of discal cell; two vertical mirrored dark brown stripes in the discal cell closure, from costal inner margin; dark brown maculae on the tornus region, merged with the post discal bands on the 
308 scales; underside with the same dorsal pattern but with light brown background and rusty brown

309 bands. Hindwing with the same forewing pattern, except for the darker apex and the delineated

310 post discal bands. Abdomen: Dorsally olive green on segments A1-A2, beige on segments A3-

311 A7, ventrally beige. Genitalia (Fig. 5): Seventh sternite smooth; ostium sclerotized not fused

312 with the seventh sternite; antrum short and membranous, except for a sclerotized ring close to

313 corpus bursae; ductus bursae short and membranous; corpus bursae extending beyond the

314 seventh sternite, signa consisting of several microspicles and a falciform spine. Bulla seminallis

315 arising from a ventral pouch on the posterior portion of corpus bursae Lamella antevaginalis

316 absent. Lamella postvaginalis sclerotized, square shaped.

317 Etymology. The specific epithet oxum comes from Yoruba "Oșun”. It is the Brazilian

318 name of the female orisha and river deity who reigns over fresh waters. In the native culture of

319 the Yoruba people, orishas represent spirits sent for the guidance of all creation and of humanity.

320 Oxum is considered the lady of beauty, fertility, money and sensitivity. Its name derives

321 from the Oṣun River, which flows in Yorubaland, the Nigerian region of Ìjẹșà. The specific

322 epithet is a tribute to women and to Brazilian black culture. A noun in apposition.

323 Distribution. The single record came from a site of montane rainforest in a region with

324 elevations ranging from $800 \mathrm{~m}$ to $1000 \mathrm{~m}$ a.s.1. in the Serra do Mar mountain chain, in São Paulo

325 State.

Remarks: Eois oxum is represented by a singleton collected on a lightrap. Despite having

327 returned to the sampling site several times no additional individuals were collected. Regardless

328 of having just one specimen available, the idiosyncratic wing pattern and the morphology of

329 genilalia justifies the description of this new taxon based only on the holotype. 
331 Boraceia, $23^{\circ} 39^{\prime} \mathrm{S} 45^{\circ}$ 54’W, 850m asl, 28-X/ 01-XI-2016, Simeão M., Tamara A. \& André T

332 leg. Deposited in the Zoology Collection of the Museu da Biodiversidade da Universidade

333 Estadual de Campinas (ZUEC), Campinas, São Paulo, Brazil.

\section{Discussion}

Although the diversity of Eois has been highlighted in previous studies based on molecular evidence (Strutzenberger et al. 2011, Wilson et al. 2012, Moraes et al. submitted), the lack of researchers working on this diversity and providing stability for the names through formal description of new taxa precluded a comprehensive taxonomic treatment so that the proper description of this huge diversity remains a taxonomic challenge.

In the present study, we provided a preliminary taxonomic assessment for a small clade

342 of Eois; a broader taxonomic sampling and additional evidence (molecular and morphological)

343 will be needed to deal with larges clades, such as those of E. olivacea and E. tegularia. In short, 344 although the present study is a small contribution for a clade that is clearly composed of a large 345 number of species, including several complexes of cryptic species, we hope that it contributes to 346 a better understanding of the genus Eois. Moreover, we believe that forthcoming studies in this 347 group can take advantage of several sources of evidence, including morphology, molecular data 348 and host plant use among other not yet properly explored (e.g. data from immature stages). In

349 this context of integrative taxonomy, the distinct evolutionary lineages (i.e., distinct species) can 350 be better recognized and defined, unveiling the real biodiversity of this large genus of moths. 
353 We are grateful to André Rangel Nascimento and Tara Joy Massad for providing some of the

354 Eois samples used here and to Thamara Zacca for critical reading of the manuscript. This study

355 is part of the project Dimensions US-Biota São Paulo: "Chemically mediated multi-trophic

356 interaction diversity across tropical gradients" (Fapesp 2014/50316-7).

\section{References}

358 Birket-Smith J. 1974. Morphology of the male genitalia of Lepidoptera I. Ditrysia.

359 Entomologica Scandinavica 5: 1-22.

360 Brehm G, Bodner F, Strutzenberger P, Hünefeld F, Fiedler K. 2011. Neotropical Eois 361 (Lepidoptera: Geometridae): Checklist, Biogeography, Diversity and Description Patterns. 362 Annals of the Entomological society of America, 104: 1091-1107.

363 Carstens BC, Pelletier TA, Reid NM, Salter, JD. 2013. How to fail at species delimitation. 364 Molecular Ecology 22: 4369-4383.

365 Galicia I, Sánchez V, Cordeiro C. 2008. On the function of signa, a genital trait of female 366 Lepidoptera. Annals of the Entomological Society of America $367 \quad 101: 786-793$.

368 Hoang DT, Chernomor O, von Haeseler A, Minh BQ, Vinh LS. 2018. UFBoot2:

369 Improving the Ultrafast Bootstrap Approximation. Molecular Biology and Evolution 35: 518$370 \quad 522$.

371 Holloway JD. 1997. The moths of Borneo. Part 10. Geometridae Sterrhinae, Larentiinae. 372 Malayan Nature Journal 51: 1-242.

373 Hulst GD. 1896. A classification of the Geometrina of North América, with descriptions of new 374 genera and species. Transactions of the American Entomological Society 23: 245-386. 
375 Katoh K, Misawa K, Kuma K, Miyata T. 2002. MAFFT: a novel method for rapid multiple 376 alignment based on fast Fourier transform. Nucleic Acids Research 14: 3059-3066.

377 Kearse M, Moir R, Wilson A, Stones-Havas S, Cheung M, Sturrock S, Buxton S, Cooper A, 378 Markowitz S, Duran C, Thierer T, Ashton B, Mentjies P, Drummond A. 2012. Geneious 379 Basic: an integrated and extendable desktop software platform for the organization and 380 analysis of sequence data.

381 Klots A B. 1956. Lepidoptera. In: Tuxen LS, ed. Taxonomist's glossary of 382 genitalia in insects. Copenhagen: Munksgaard, 97-110.

383 Miller MA, Pfeiffer W, Schwartz T. 2010. Creating the CIPRES science gateway for inference of 384 large phylogenetic trees. Gateway Computing Environments Workshop 2010: 1-8.

385 Mitter C, Davis, DR, Cummings MP. 2017. Phylogeny and evolution of Lepidoptera. Annual 386 Review of Entomology 62: 265-283.

387 Moraes SS. Duarte M. 2009. Morfologia comparada das três espécies do complexo Telchin licus 388 (Drury) (Lepidoptera, Castniidae) com nova sinonímia. Revista Brasileira de Entomologia. $38953: 245-265$.

390 Mutuura A. 1972. Morphology of the female terminalia in Lepidoptera, and its taxonomic 391 significance. Canadian Entomologist 104: 1055-1071.

392 Ogata M, Okada Y, Okagaki H, Sibatani A. 1957. Male genitalia of Lepidoptera: morphology 393 and nomenclature III. Appendages pertaining to the tenth somite. Annals of the 394 Entomological Society of America 50: 237-244.

395 Okagaki H, Sibatani A, Ogata M, Okada Y. 1955. Male genitalia of Lepidoptera: morphology 396 and nomenclature II. Morphological significance of sacculus and furca. Annals of the 397 Entomological Society of America 8: 438-442. 
398 Pierce FN. 1909. The genitalia of the group Noctuidae of the Lepidoptera of the British Islands.

399 An account of the morphology of the male clasping organs. A. W. Duncan. Liverpool. 88 pp.

400 Pierce FN 1914. The genitalia of the group Geometridae of the Lepidoptera of the British

401 Islands. An account of the morphology of the male clasping organs and the corresponding

402 organs of the female. A. W. Duncan. Liverpool. 84 pp.

403 Pitkin LM. 2002. Neotropical ennomine moths: a review of the genera (Lepidoptera:

404 Geometridae). Zoological Journal of the Linnean Society 135: 121-401.

405 Puillandre N, Lambert A, Brouillet S, Achaz G. 2012. ABGD, automatic barcode gap discovery 406 for primary species delimitation. Molecular Ecology 21: 1864-1877.

407 Rindge FH. 1990. A revision of the Melanolophiini (Lepidoptera, Geometridae). Bulletin of the 408 American Museum of Natural History 199: 1-148.

409 Sibatani A, Ogata M, Okada Y, Okagaki H. 1954. Male genitália of Lepidoptera: morphology 410 and nomenclature. I. Divisions of the valvae in Rhopalocera, Phalaenidae (= Noctuidae) and 411 Geometridae. Annals of Entomological Society of America 47: 93-106.

412 Scoble, MJ. 1999. A taxonomic catalogue to the Geometridae of the world (Insecta: 413 Lepidoptera). 2 vols. CSIRO Publications.

414 Sihvonen P, Mutanen M, Kaila L, Brehm G, Hausmann A, Straude HS. 2011. Comprehensive 415 molecular sampling yields a robust phylogeny for geometrid moths (Lepidoptera: 416 Geometridae). PLOS ONE 6:e20356.

417 Stamatakis A. 2014. RAxML version 8: a tool for phylogenetic analysis and post-analysis of $418 \quad$ large phylogenies. Bioinformatics 30: 1312-1313.

419 Strutzenberger P, Brehm G, Bodner F, Zimmermann M, Wiemers M, Fiedler K. 2011. DNA 420 barcoding-based species delimitation increases species count of Eois (Geometridae) moths in 
421 a well-studied tropical mountain forest by up to 50\%. Insect Science 18: 349-362.

422 Strutzenberger P, Brehm G, Fiedler K. 2012. DNA Barcode sequencing from old type specimens 423 as a tool in taxonomy: a case study in the diverse genus Eois (Lepidoptera: Geometridae). 424 Plos One 7(11): e49710. doi: 10.1371/journal.pone.0049710. Epub 2012 Nov 21.

425 Wehrli E. 1939-1954. Subfamilie: Geometrinae. In: SEITZ, A. (ed.). Die Gross Schmetterlinge 426 der Erde. Abt. I. Die Spannerartigen Nachtfalter. Bd. 4 (Supplement): 254-722, pls. 19-53. 427 Verlag, A. Kernen, Stuttgart.

428 Winter WD. 2000. Basic techniques for observing and studying moths and butterflies. Memoirs 429 of the Lepidopterists' Society 5: 1-444.

430

431

432

433

434

435

436 Figure Captions

437

438 Fig 1. Gene tree for the DNA barcode marker (COI or cox1). Colored leaves represent host 439 plants for clades where adult representatives were obtained from reared immatures. Numbers on 440 the nodes represents ultrafast bootstrap (UFBoot2) stability equal or above 96\%. Photographs by 441 Simeão Moraes and Mariana Stanton.

442

443 Fig 2. Habitus of Eois holotypes specimens. A-B. Male, holotype of Eois oya sp.nov. A. Dorsal 444 view. B. Ventral view. C-D. Male, holotype of Eois ewa sp.nov. C., Dorsal view. D. Ventral 445 view. E-F. Female, holotype of Eois oxum sp.nov. Scale bar 1 cm. Photographs by Simeão 446 Moraes. 
448 Fig 3. Male and female genitalia of Eois oya sp.nov. paratype A. Male genitalia, genital capsule, 449 dorsal view. B. Male genitalia, genital capsule, ventral view C. Male genitalia, genital capsule, 450 lateral view. D. Male genitalia, aedeagus, lateral view. E. Female genitalia, dorsal view. Scale 451 bar 1mm. Line drawings by Simeão Moraes and Ygor Montebello.

452

453 Fig 4. Male and female genitalia of Eois ewa sp.nov. paratype. A. Male genitalia, genital 454 capsule, dorsal view. B. Male genitalia, genital capsule, ventral view C. Male genitalia, genital 455 capsule, lateral view. D. Male genitalia, aedeagus, lateral view. E. Female genitalia, lateral view. 456 Scale bar 1mm. Line drawings by Simeão Moraes.

457

458 Fig 5. Female genitalia of Eois oxum sp.nov. holotype. A. Genitalia, dorsal view. B. Genitalia, 459 ventral view C. Genitalia, lateral view. Scale bar $1 \mathrm{~mm}$. Line drawings by Simeão Moraes.

460

461

Author Contribution Statements

462 SSM, MAS, LFY and MJK collected the samples. MAS and LFY reared the imatures. SSM and YZM performed laboratory protocols. SSM, YZM, MAS and AVLF conceived the ideas for the manuscript. SSM and YZM analyzed the data. SSM, YZM and MAS interpreted the results. MJK acquired the funding. YZM and SSM did the line drawings. SSM wrote the main manuscript. All authors reviewed the manuscript. 
Figure 1

Gene tree for COI-begin marker

Colored leaves represent host plants for clades where adult representatives were obtained from reared immatures. Numbers on the node represents bootstrap stability equal or above 96\%. Photographs by Simeão Moraes and Mariana Stanton. 


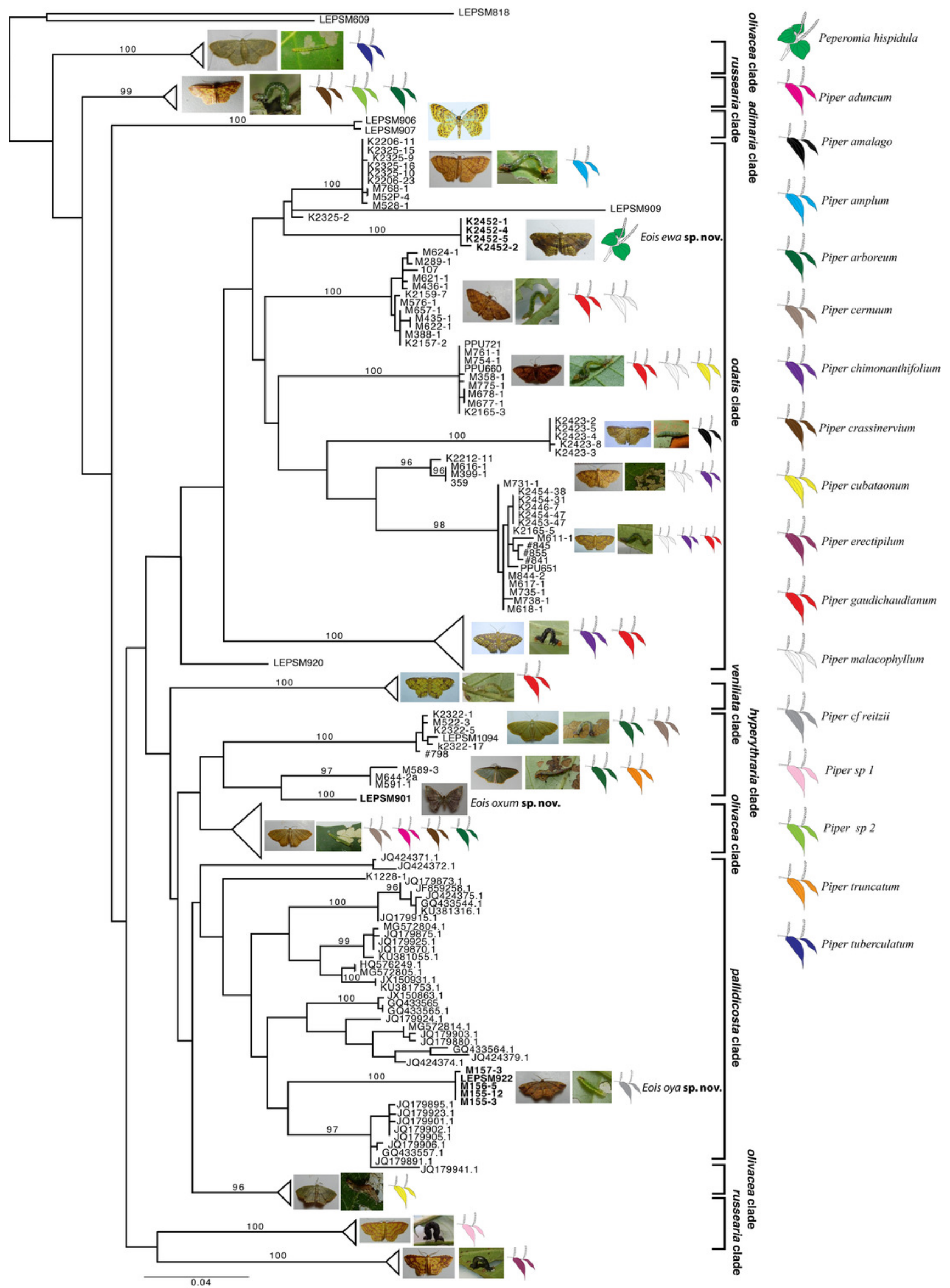


Figure 2

Habitus of Eois holotypes specimens

A-B. Male, holotype of Eois oya sp.nov. A. Dorsal view. B. Ventral view. C-D. Male, holotype of Eois ewa sp.nov. C., Dorsal view. D. Ventral view. E-F. Female, holotype of Eois oxum sp.nov. Scale bar $1 \mathrm{~cm}$. Photographs by Simeão Moraes. 


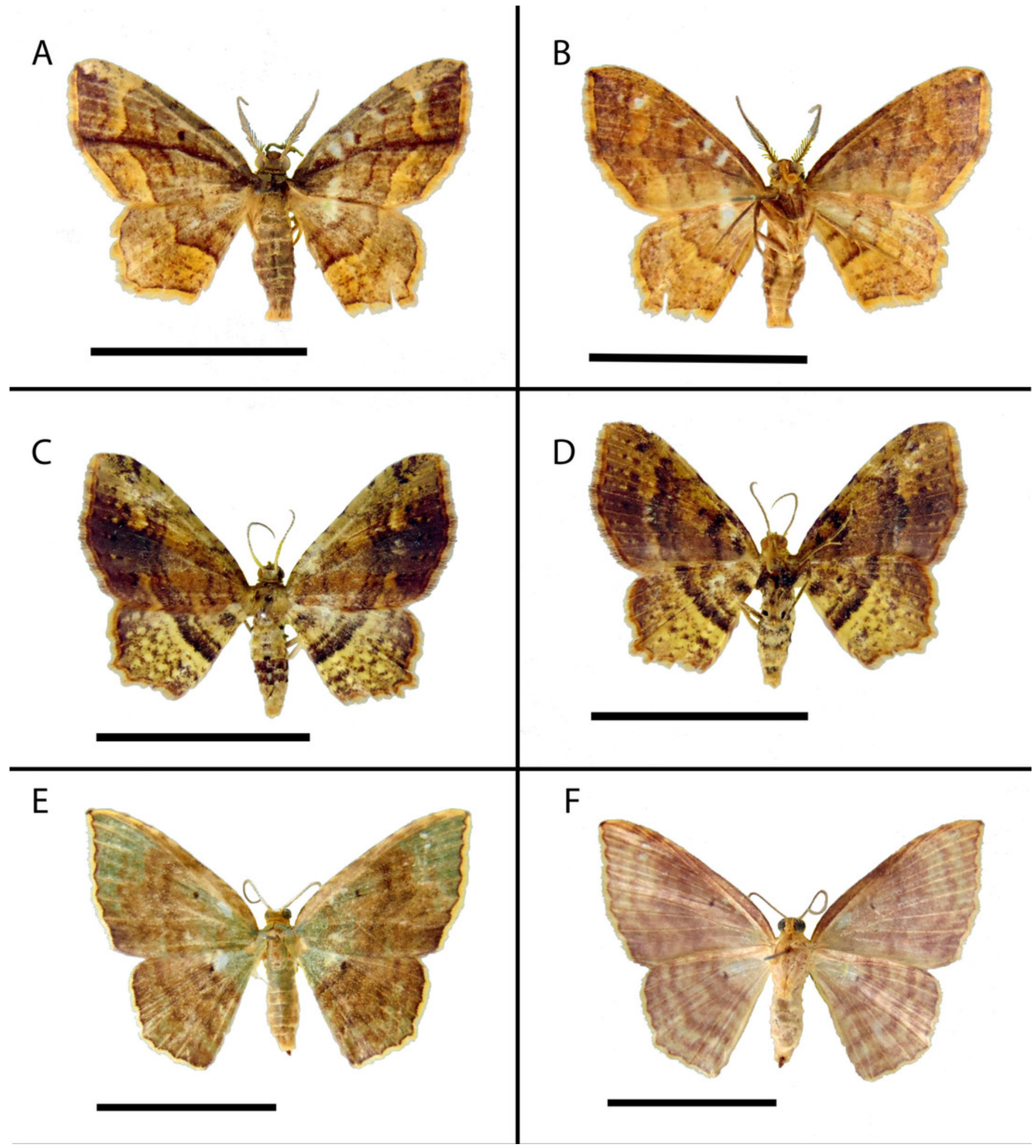


Figure 3

Male and female genitalia of Eois oya sp.nov. paratype

A. Male genitalia, genital capsule, dorsal view. B. Male genitalia, genital capsule, ventral view

C. Male genitalia, genital capsule, lateral view. D. Male genitalia, aedeagus, lateral view. E.

Female genitalia, dorsal view. Scale bar $1 \mathrm{~mm}$. Line drawings by Simeão Moraes and Ygor

Montebello 
A

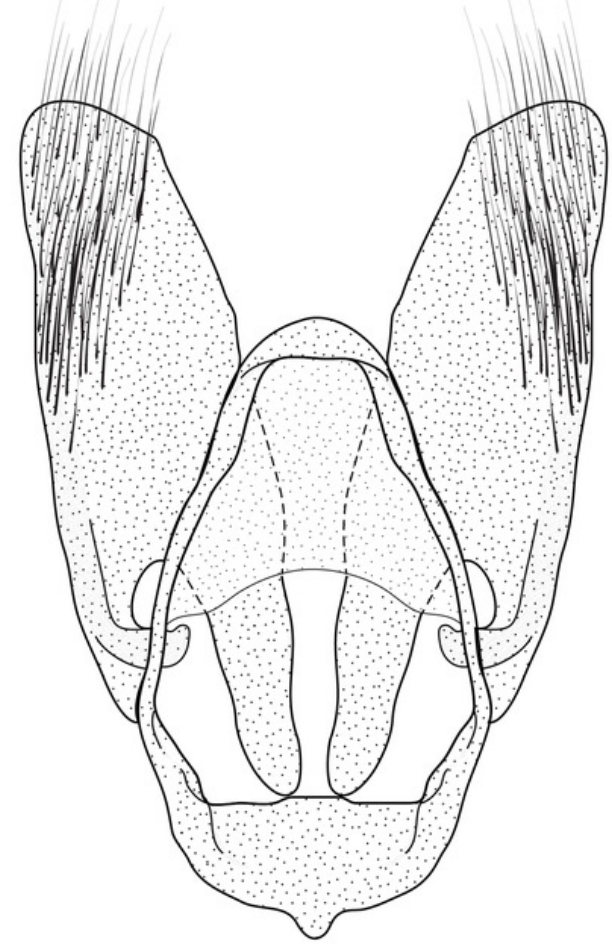

B
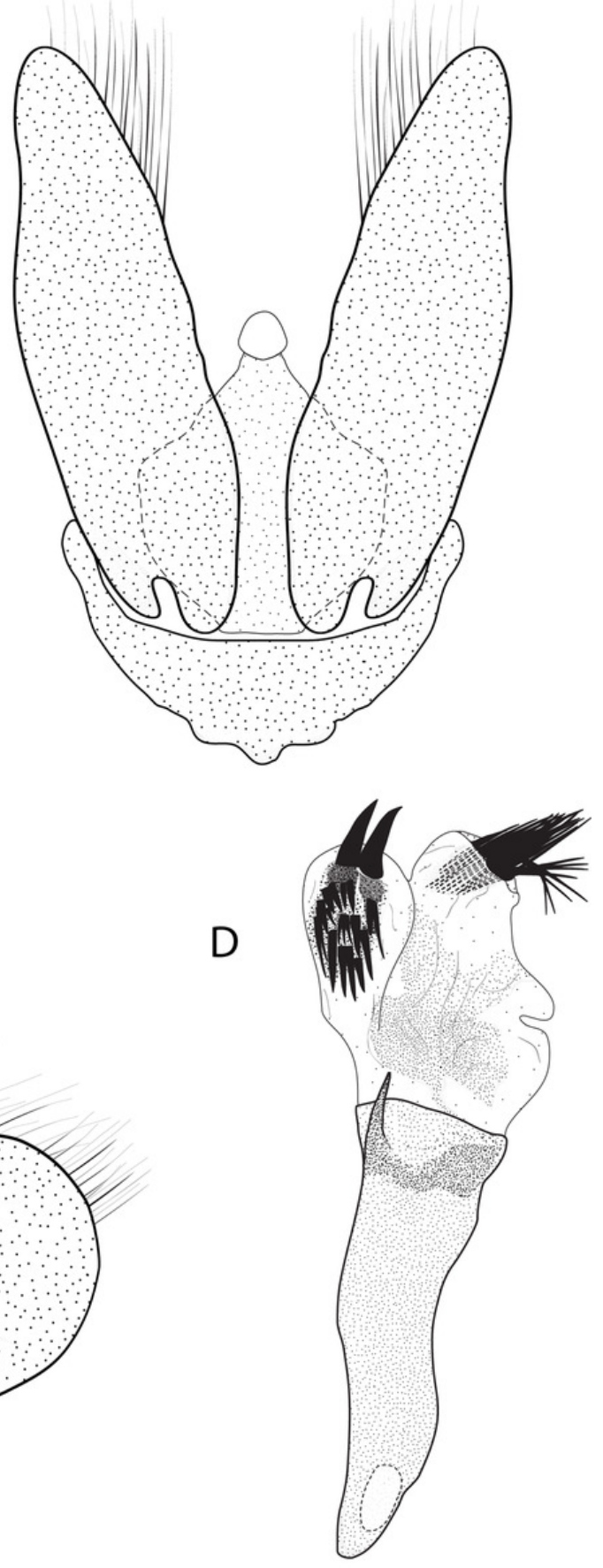

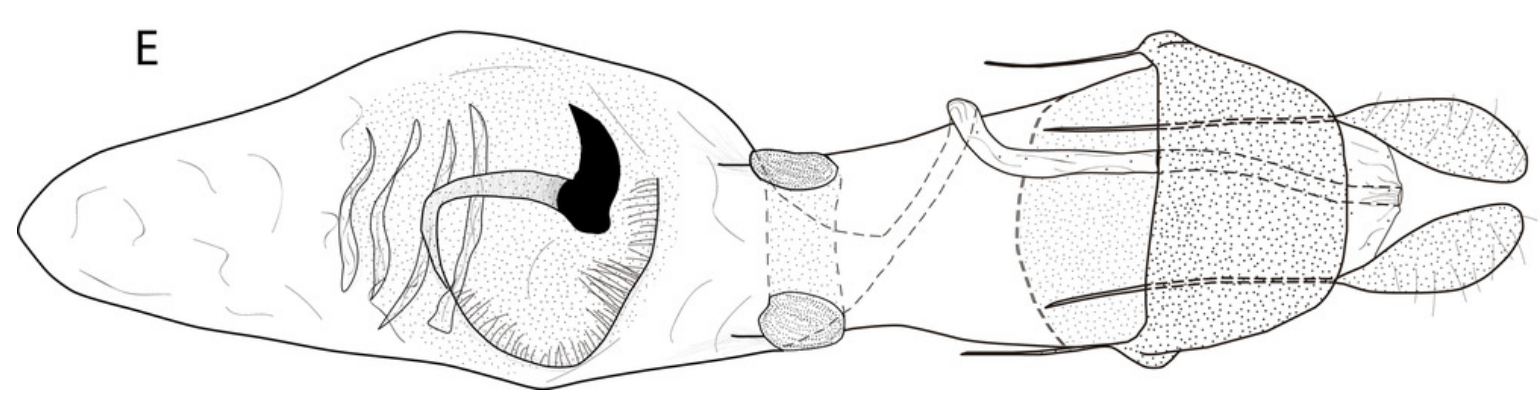

Peer] reviewing PDF | (2020:12:56418:1:1:NEW 4 Mar 2021) 
Figure 4

Male and female genitalia of Eois ewa sp.nov. paratype

A. Male genitalia, genital capsule, dorsal view. B. Male genitalia, genital capsule, ventral view

C. Male genitalia, genital capsule, lateral view. D. Male genitalia, aedeagus, lateral view. E.

Female genitalia, lateral view. Scale bar $1 \mathrm{~mm}$. Line drawings by Simeão Moraes. 
A
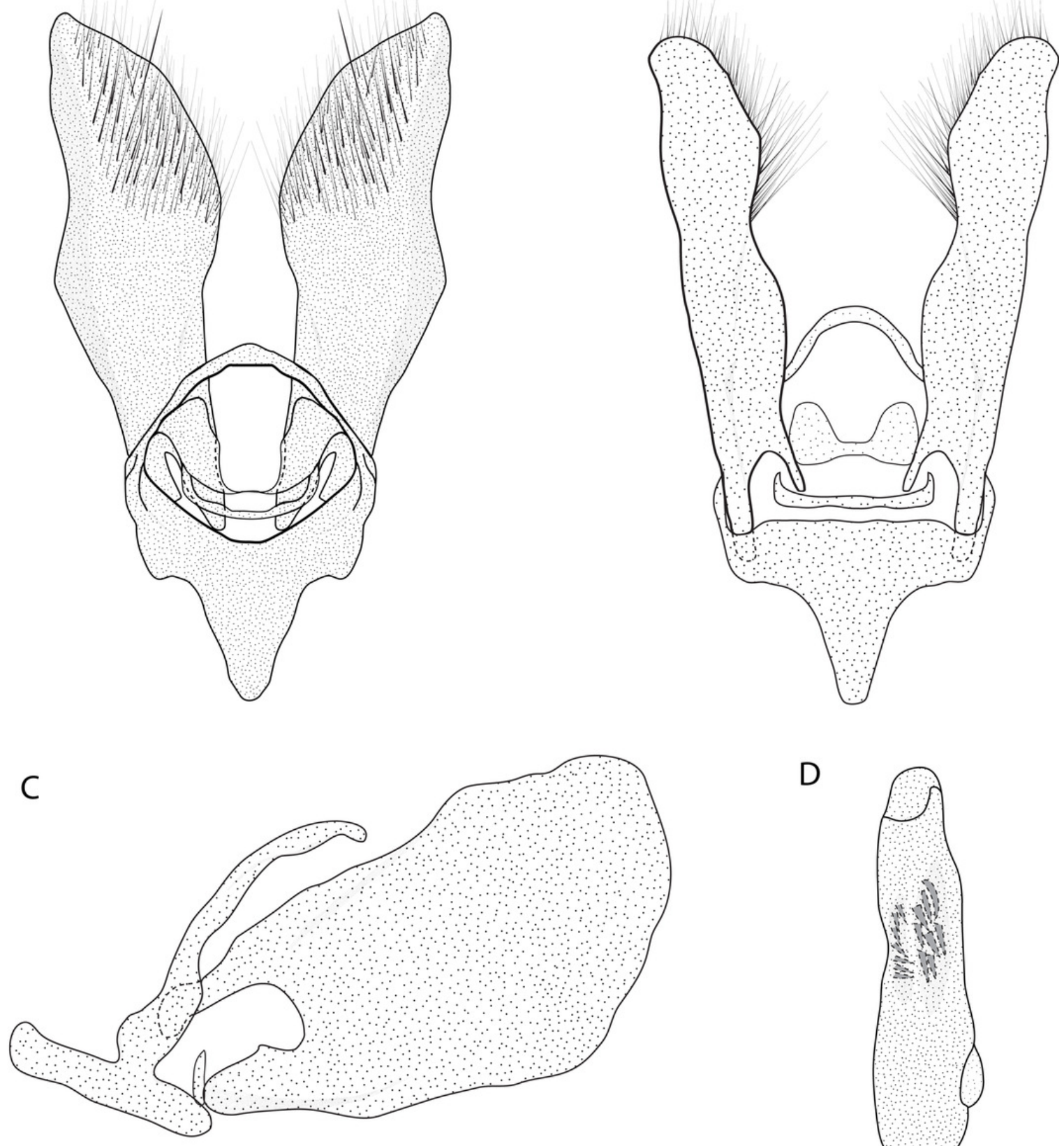

E

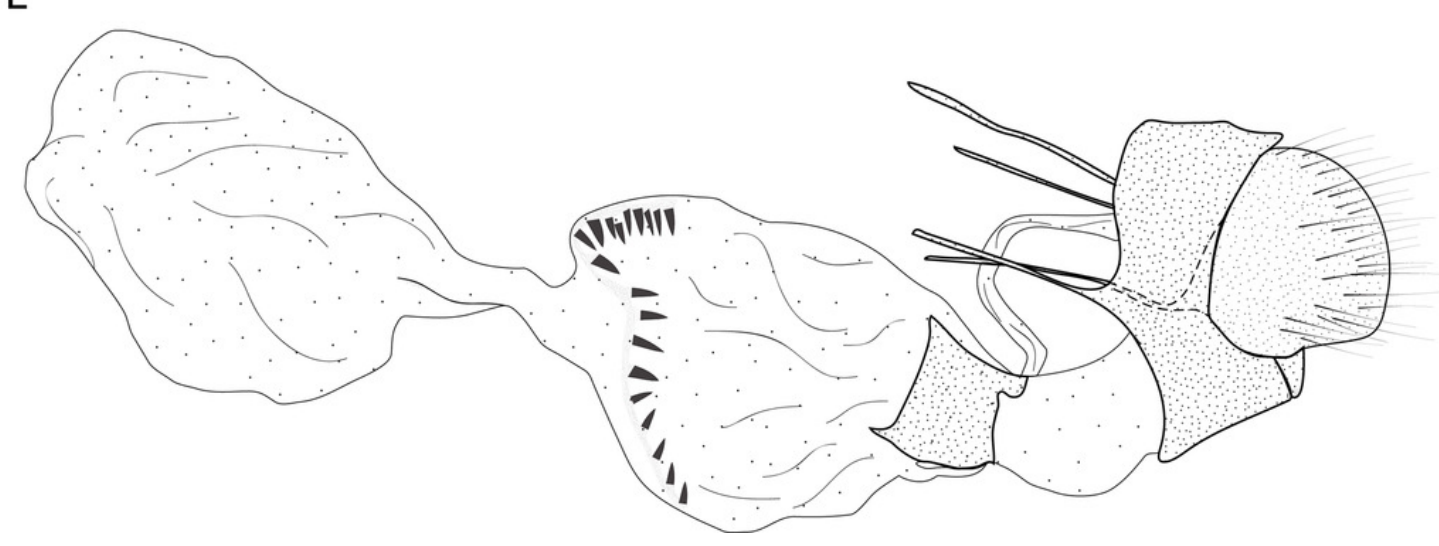


Figure 5

Female genitalia of Eois oxum sp.nov. holotype

A. Genitalia, dorsal view. B. Genitalia, ventral view C. Genitalia, lateral view. Scale bar 1mm. Line drawings by Simeão Moraes 
A

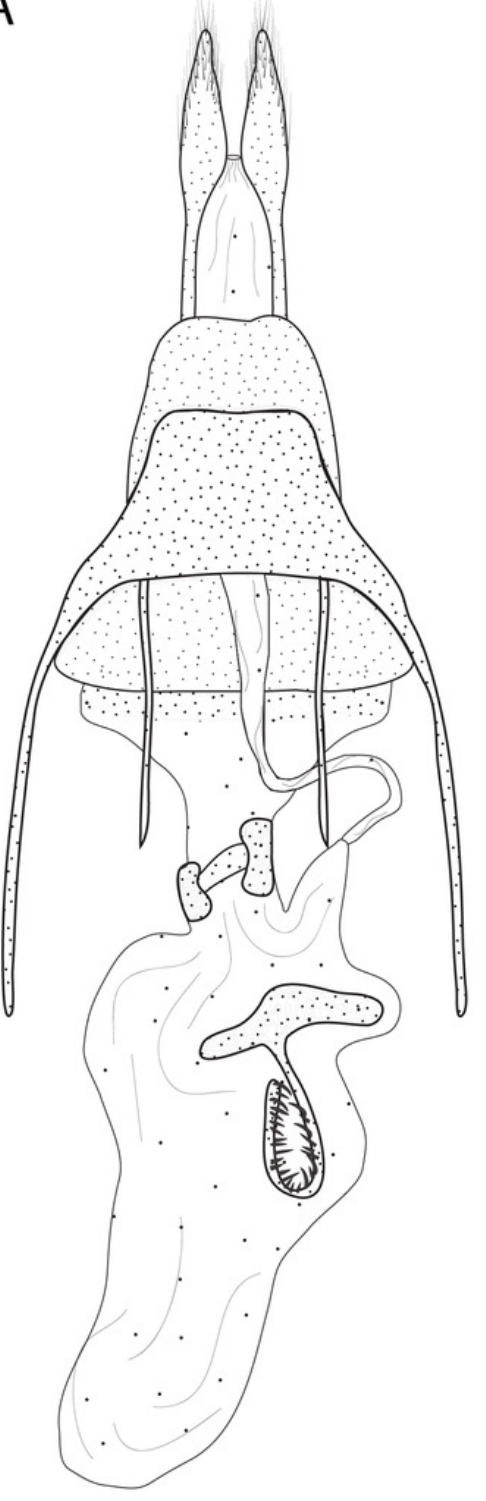

B

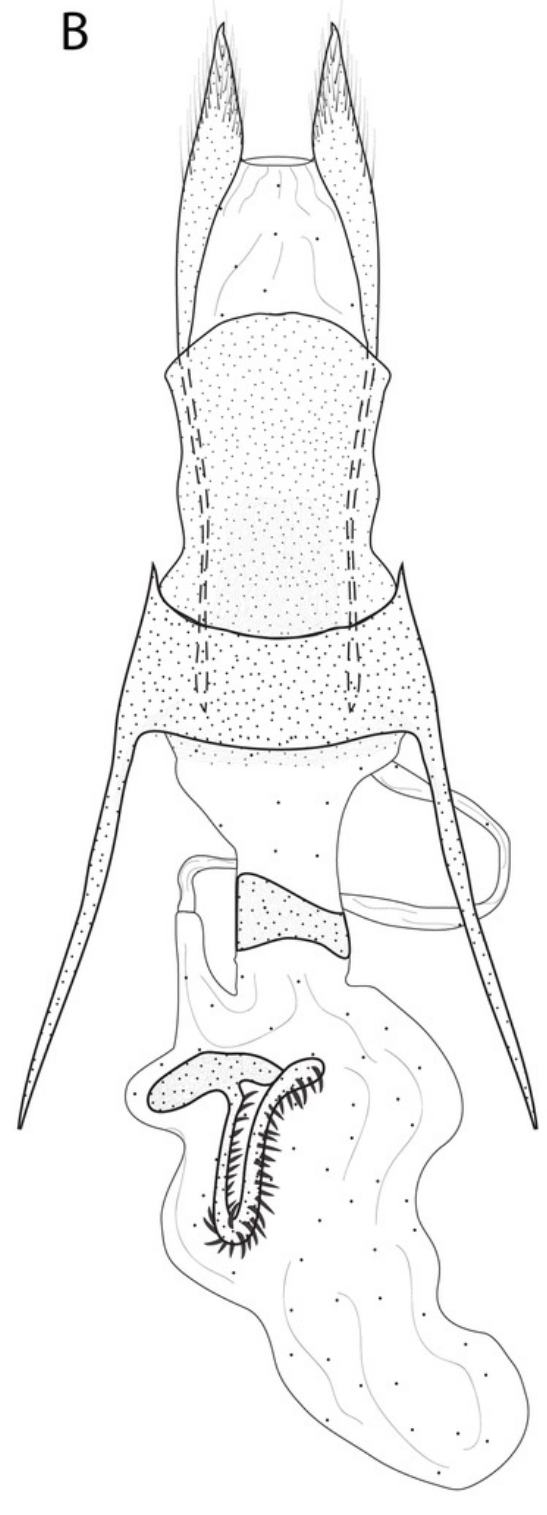

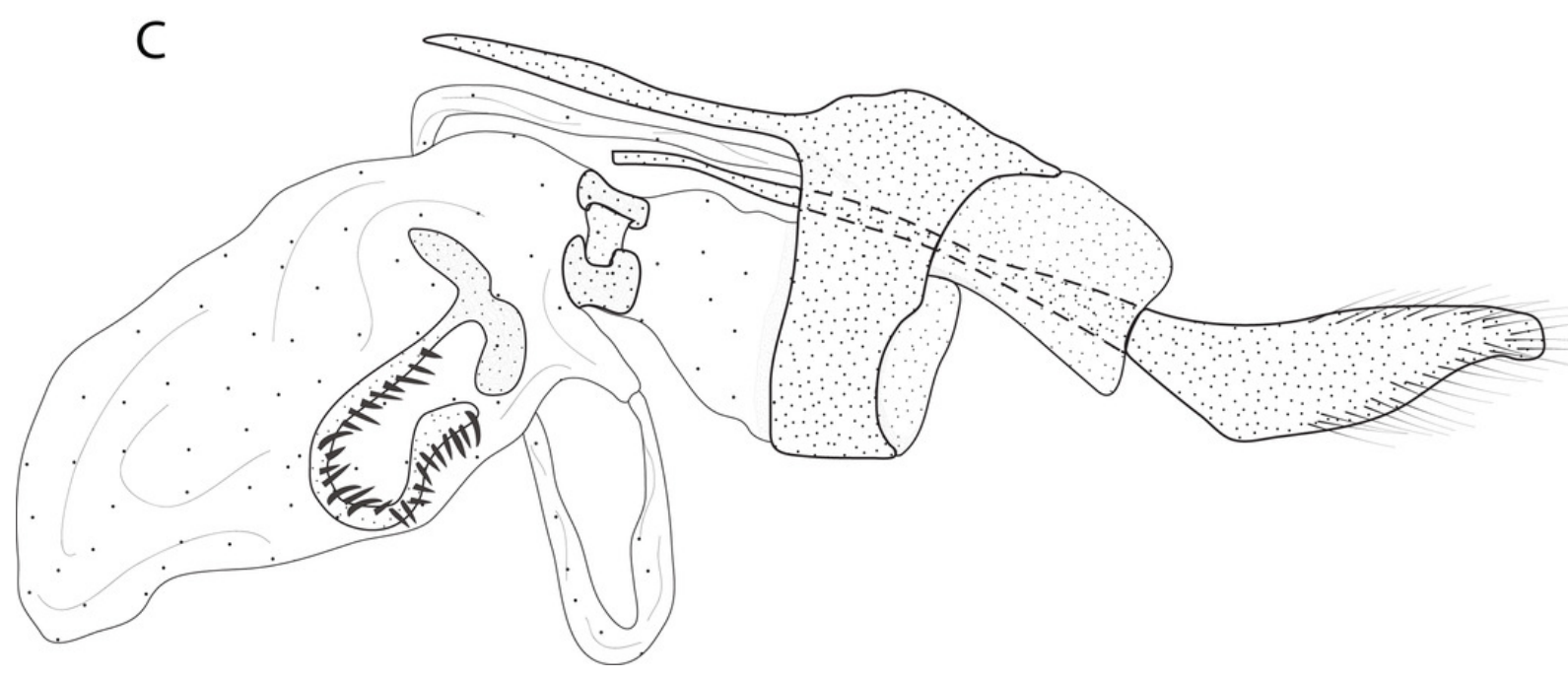

PeerJ reviewing PDF | (2020:12:56418:1:1:NEW 4 Mar 2021) 


\section{Table $\mathbf{1}$ (on next page)}

Table 1. List of specimens vouchered, the associated clade, geographical localities, host plant and herbarium voucher for host plants used in this study.

Herbarium specimens that were identified by comparison to previously collected samples deposited at the University of São Paulo Herbarium (SPF) are reported with (*). 
Table 1. List of specimens vouchered, the associated clade, geographical localities, host plant and herbarium voucher for host plants used in this study. Herbarium specimens that were identified by comparison to previously collected and identified herbarium samples at Laboratório de Química de Produtos Naturais, and deposited at the University of São Paulo Herbarium (SPF) are reported with (*).

\begin{tabular}{|c|c|c|c|c|}
\hline Genbank Voucher & Clade & Locality & Host Plant & Herbarium Voucher \\
\hline \multicolumn{5}{|l|}{ LEPSM818 } \\
\hline \multicolumn{5}{|l|}{ LEPSM609 } \\
\hline K2422-1 & olivacea & Brazil, MS, Aquidauana & Piper tuberculatum Jacq. & K2422 \\
\hline K2422-1a & olivacea & Brazil, MS, Aquidauana & Piper tuberculatumJacq. & K2422 \\
\hline K2426-2 & olivacea & Brazil, MS, Aquidauana & Piper tuberculatumJacq. & $\mathrm{K} 2422$ \\
\hline K2426-3 & olivacea & Brazil, MS, Aquidauana & Piper tuberculatumJacq. & $\mathrm{K} 2422$ \\
\hline M097-1 & russearia & Brazil, SP, Mogi-Guaçu, Reserva Biológica de Mogi-Guaçu & Piper arboreumAubl. & K1953* \\
\hline Mogi\#906 & russearia & Brazil, SP, Mogi-Guaçu, Reserva Biológica de Mogi-Guaçu & Piper arboreumAubl. & K1953* \\
\hline M081-1 & russearia & Brazil, SP, Mogi-Guaçu, Reserva Biológica de Mogi-Guaçu & Piper crassinerviumKunth. & K1954* \\
\hline Mogi\#802 & russearia & Brazil, SP, Mogi-Guaçu, Reserva Biológica de Mogi-Guaçu & Piper crassinerviumKunth. & K1954* \\
\hline M076-1 & russearia & Brazil, SP, Mogi-Guaçu, Reserva Biológica de Mogi-Guaçu & Piper crassinerviumKunth. & K1954* \\
\hline M081-2 & russearia & Brazil, SP, Mogi-Guaçu, Reserva Biológica de Mogi-Guaçu & Piper crassinerviumKunth. & K1954* \\
\hline Mogi\#818 & russearia & Brazil, SP, Mogi-Guaçu, Reserva Biológica de Mogi-Guaçu & Piper crassinerviumKunth. & K1954* \\
\hline K2411-2 & russearia & Brazil, MS, Aquidauana & Piper sp 2 & K2417 \\
\hline $\mathrm{K} 2417-12$ & russearia & Brazil, MS, Aquidauana & Piper sp 2 & K2417 \\
\hline K2417-7 & russearia & Brazil, MS, Aquidauana & Piper sp 2 & K2417 \\
\hline K2417-27 & russearia & Brazil, MS, Aquidauana & Piper sp 2 & K2417 \\
\hline K2416-16 & russearia & Brazil, MS, Aquidauana & Piper sp 2 & K2417 \\
\hline LEPSM906 & adimaria & & & \\
\hline LEPSM907 & adimaria & & & \\
\hline K2206-1 & odatis & Brazil, SP, Jundiaí, Reserva Biológica da Serra do Japi & Piper amplumKunth. & K2493 \\
\hline K2325-15 & odatis & Brazil, SP, Jundiaí, Reserva Biológica da Serra do Japi & Piper amplumKunth. & K2493 \\
\hline K2325-9 & odatis & Brazil, SP, Jundiaí, Reserva Biológica da Serra do Japi & Piper amplumKunth. & K2493 \\
\hline K2325-16 & odatis & Brazil, SP, Jundiaí, Reserva Biológica da Serra do Japi & Piper amplumKunth. & K2493 \\
\hline K2325-10 & odatis & Brazil, SP, Jundiaí, Reserva Biológica da Serra do Japi & Piper amplumKunth. & K2493 \\
\hline K2206-23 & odatis & Brazil, SP, Jundiaí, Reserva Biológica da Serra do Japi & Piper amplumKunth. & K2493 \\
\hline
\end{tabular}




\begin{tabular}{|c|c|c|c|c|}
\hline M768-1 & odatis & Brazil, SP, Jundiaí, Reserva Biológica da Serra do Japi & Piper amplumkunth. & M1033 \\
\hline M528-4 & odatis & Brazil, RJ, Itatiaia, Parque Nacional de Itatiaia & Piper amplumKunth. & M1033 \\
\hline M528-1 & odatis & Brazil, RJ, Itatiaia, Parque Nacional de Itatiaia & Piper amplumKunth. & M1033 \\
\hline LEPSM909 & odatis & & & \\
\hline K2325-2 & odatis & Brazil, SP, Jundiaí, Reserva Biológica da Serra do Japi & Piper amplumKunth. & K2493 \\
\hline K2452-1 & odatis & Brazil, RJ, Itatiaia, Parque Nacional de Itatiaia & Peperomia hispidula(Sw.) A. Dietr. & K1612* \\
\hline K2452-4 & odatis & Brazil, RJ, Itatiaia, Parque Nacional de Itatiaia & Peperomia hispidula(Sw.) A. Dietr. & K1612* \\
\hline K2452-5 & odatis & Brazil, RJ, Itatiaia, Parque Nacional de Itatiaia & Peperomia hispidula(Sw.) A. Dietr. & K1612* \\
\hline K2452-2 & odatis & Brazil, RJ, Itatiaia, Parque Nacional de Itatiaia & Peperomia hispidula(Sw.) A. Dietr. & K1612* \\
\hline M624-1 & odatis & Brazil, RJ, Itatiaia, Parque Nacional de Itatiaia & Piper malacophyllumC. Presl & M1038 \\
\hline M289-1 & odatis & Brazil, SP, São Paulo, Parque Estadual do Pico do Jaraguá & Piper malacophyllumC. Presl & K2294* \\
\hline$\# 107$ & odatis & & & \\
\hline M621-1 & odatis & Brazil, RJ, Itatiaia, Parque Nacional de Itatiaia & Piper malacophyllumC. Presl & M1038 \\
\hline M436-1 & odatis & Brazil, SP, São Paulo, Parque Estadual do Pico do Jaraguá & Piper malacophyllumC. Presl & K2294* \\
\hline K2159-7 & odatis & Brazil, RJ, Itatiaia, Parque Nacional de Itatiaia & Piper malacophyllumC. Presl & K2159 \\
\hline M576-1 & odatis & Brazil, RJ, Itatiaia, Parque Nacional de Itatiaia & Piper malacophyllumC. Presl & M1038 \\
\hline M657-1 & odatis & Brazil, SP, São Paulo, Parque Estadual do Pico do Jaraguá & Piper gaudichaudianumKunth. & $\mathrm{K} 2311^{*}$ \\
\hline M435-1 & odatis & Brazil, SP, São Paulo, Parque Estadual do Pico do Jaraguá & Piper malacophyllumC. Presl & K2294* \\
\hline M622-1 & odatis & Brazil, RJ, Itatiaia, Parque Nacional de Itatiaia & Piper malacophyllumC. Presl & M1038 \\
\hline M388-1 & odatis & Brazil, SP, São Paulo, Parque Estadual do Pico do Jaraguá & Piper gaudichaudianumKunth. & K2311* \\
\hline K2157-2 & odatis & Brazil, RJ, Itatiaia, Parque Nacional de Itatiaia & Piper malacophyllumC. Presl & K2165 \\
\hline PPU721 & odatis & Brazil, SP, Jundiaí, Reserva Biológica da Serra do Japi & Piper malacophyllumC. Presl & K2306 \\
\hline M761-1 & odatis & Brazil, SP, Jundiaí, Reserva Biológica da Serra do Japi & Piper gaudichaudianumKunth. & K2198* \\
\hline M754-1 & odatis & Brazil, SP, Jundiaí, Reserva Biológica da Serra do Japi & Piper gaudichaudianumKunth. & K2198* \\
\hline PPU660 & odatis & Brazil, SP, Jundiaí, Reserva Biológica da Serra do Japi & Piper malacophyllumC. Presl & K2306 \\
\hline M358-1 & odatis & Brazil, SP, São Paulo, Parque Estadual do Pico do Jaraguá & Piper cubataonum C DC. & K1951* \\
\hline M775-1 & odatis & Brazil, SP, Jundiaí, Reserva Biológica da Serra do Japi & Piper gaudichaudianumKunth. & K2198* \\
\hline M678-1 & odatis & Brazil, SP, São Paulo, Parque Estadual do Pico do Jaraguá & Piper malacophyllumC. Presl & K2294* \\
\hline M677-1 & odatis & Brazil, SP, São Paulo, Parque Estadual do Pico do Jaraguá & Piper gaudichaudianumKunth. & K2311* \\
\hline K2165-3 & odatis & Brazil, RJ, Itatiaia, Parque Nacional de Itatiaia & Piper malacophyllumC. Presl & K2165 \\
\hline M514-1 & odatis & Brazil, RJ, Itatiaia, Parque Nacional de Itatiaia & Piper crassinervium Kunth. & K1954* \\
\hline
\end{tabular}




\begin{tabular}{|c|c|c|c|c|}
\hline K2423-5 & odatis & Brazil, MS, Corumbá & Piper amalago L. & K2421 \\
\hline K2423-4 & odatis & Brazil, MS, Corumbá & Piper amalago L. & K2421 \\
\hline K2423-8 & odatis & Brazil, MS, Corumbá & Piper amalago L. & K2421 \\
\hline K2423-3 & odatis & Brazil, MS, Corumbá & Piper amalago L. & $\mathrm{K} 2421$ \\
\hline $\mathrm{K} 2212-11$ & odatis & Brazil, SP, Jundiaí, Reserva Biológica da Serra do Japi & Piper malacophyllumC. Presl & $\mathrm{K} 2212$ \\
\hline M616-1 & odatis & Brazil, RJ, Itatiaia, Parque Nacional de Itatiaia & Piper chimonanthifolium Kunth. & K1960* \\
\hline M399-1 & odatis & Brazil, SP, São Paulo, Parque Estadual do Pico do Jaraguá & Piper malacophyllumC. Presl & K2294* \\
\hline$\# 359$ & odatis & & & \\
\hline M731-1 & odatis & Brazil, SP, Jundiaí, Reserva Biológica da Serra do Japi & Piper chimonanthifolium Kunth. & K1960* \\
\hline K2454-38 & odatis & Brazil, SP, Campos do Jordão & Piper gaudichaudianumKunth. & $\mathrm{K} 2446$ \\
\hline K2454-31 & odatis & Brazil, SP, Campos do Jordão & Piper gaudichaudianumKunth. & K2446 \\
\hline K2446-7 & odatis & Brazil, SP, Campos do Jordão & Piper gaudichaudianumKunth. & $\mathrm{K} 2446$ \\
\hline K2454-47 & odatis & Brazil, SP, Campos do Jordão & Piper gaudichaudianumKunth. & $\mathrm{K} 2446$ \\
\hline K2453-47 & odatis & Brazil, SP, Campos do Jordão & Piper gaudichaudianumKunth. & K2446 \\
\hline K2165-5 & odatis & Brazil, RJ, Itatiaia, Parque Nacional de Itatiaia & Piper malacophyllumC. Presl & K2165 \\
\hline M611-1 & odatis & Brazil, RJ, Itatiaia, Parque Nacional de Itatiaia & Piper chimonanthifolium Kunth. & K1960* \\
\hline$\# 845$ & odatis & Brazil, SP, Mogi-Guaçu, Reserva Biológica de Mogi-Guaçu & Piper gaudichaudianumKunth. & \\
\hline$\# 855$ & odatis & Brazil, SP, Mogi-Guaçu, Reserva Biológica de Mogi-Guaçu & Piper gaudichaudianumKunth. & \\
\hline$\# 841$ & odatis & Brazil, SP, Mogi-Guaçu, Reserva Biológica de Mogi-Guaçu & Piper gaudichaudianumKunth. & \\
\hline PPU651 & odatis & Brazil, SP, Jundiaí, Reserva Biológica da Serra do Japi & Piper hillianum C.DC. & K1920* \\
\hline M844-2 & odatis & Brazil, SP, Capão Bonito, Parque Estadual de Intervales & Piper gaudichaudianumKunth. & M1034 \\
\hline M617-1 & odatis & Brazil, RJ, Itatiaia, Parque Nacional de Itatiaia & Piper chimonanthifolium Kunth. & K1960* \\
\hline M735-1 & odatis & Brazil, SP, Jundiaí, Reserva Biológica da Serra do Japi & Piper chimonanthifolium Kunth. & K2495 \\
\hline M738-1 & odatis & Brazil, SP, Jundiaí, Reserva Biológica da Serra do Japi & Piper chimonanthifolium Kunth. & K2495 \\
\hline M618-1 & odatis & Brazil, RJ, Itatiaia, Parque Nacional de Itatiaia & Piper chimonanthifolium Kunth. & K1960* \\
\hline M573-1-4 & odatis & Brazil, RJ, Itatiaia, Parque Nacional de Itatiaia & Piper chimonanthifolium Kunth. & K1960* \\
\hline M573-1-3 & odatis & Brazil, RJ, Itatiaia, Parque Nacional de Itatiaia & Piper chimonanthifolium Kunth. & K1960* \\
\hline K2453-4-1 & odatis & Brazil, SP, Campos do Jordão & Piper gaudichaudianumKunth. & $\mathrm{K} 2446$ \\
\hline M573-1-5 & odatis & Brazil, RJ, Itatiaia, Parque Nacional de Itatiaia & Piper chimonanthifolium Kunth. & K1960* \\
\hline M163-1-1 & odatis & Brazil, RJ, Itatiaia, Parque Nacional de Itatiaia & Piper chimonanthifolium Kunth. & K1960* \\
\hline $\mathrm{K} 2453-4 \mathrm{~b}$ & odatis & Brazil, SP, Campos do Jordão & Piper gaudichaudianumKunth. & K2446 \\
\hline
\end{tabular}




\begin{tabular}{|c|c|c|c|c|}
\hline K2453-4-2 & odatis & Brazil, SP, Campos do Jordão & Piper gaudichaudianumKunth. & K2446 \\
\hline K2453-4 & odatis & Brazil, SP, Campos do Jordão & Piper gaudichaudianumKunth. & K2446 \\
\hline M573-1-2 & odatis & Brazil, RJ, Itatiaia, Parque Nacional de Itatiaia & Piper chimonanthifolium Kunth. & K1960* \\
\hline K2453-4-3 & odatis & Brazil, SP, Campos do Jordão & Piper gaudichaudianumKunth. & K2446 \\
\hline \multicolumn{5}{|l|}{ LEPSM920 } \\
\hline \multicolumn{5}{|l|}{$\# 25$} \\
\hline M022-1 & veniliata & Brazil, SP, São Paulo, Parque Estadual do Pico do Jaraguá & Piper gaudichaudianumKunth. & K2494* \\
\hline M286-1 & veniliata & Brazil, SP, São Paulo, Parque Estadual do Pico do Jaraguá & Piper gaudichaudianumKunth. & K2494* \\
\hline K2326-1 & veniliata & Brazil, SP, Jundiaí, Reserva Biológica da Serra do Japi & Piper gaudichaudianumKunth. & K2494* \\
\hline K2322-1 & hyperythraria & Brazil, SP, Jundiaí, Reserva Biológica da Serra do Japi & Piper arboreumAubl. & K1953* \\
\hline M522-3 & hyperythraria & Brazil, RJ, Itatiaia, Parque Nacional de Itatiaia & Piper cernuum Vell. & K1925* \\
\hline K2322-5 & hyperythraria & Brazil, SP, Jundiaí, Reserva Biológica da Serra do Japi & Piper arboreumAubl. & K1953* \\
\hline LEPSM1094 & hyperythraria & & & \\
\hline K2322-17 & hyperythraria & Brazil, SP, Jundiaí, Reserva Biológica da Serra do Japi & Piper arboreumAubl. & K1953* \\
\hline \#798 & hyperythraria & Brazil, SP, Mogi-Guaçu, Reserva Biológica de Mogi-Guaçu & Piper arboreumAubl. & K1953* \\
\hline M589-3 & hyperythraria & Brazil, RJ, Itatiaia, Parque Nacional de Itatiaia & Piper arboreumAubl. & K1953* \\
\hline M644-2a & hyperythraria & Brazil, RJ, Itatiaia, Parque Nacional de Itatiaia & Piper arboreumAubl. & K1953* \\
\hline M591-1 & hyperythraria & Brazil, RJ, Itatiaia, Parque Nacional de Itatiaia & Piper truncatum Vell. & K1950* \\
\hline LEPSM901 & hyperythraria & & & \\
\hline K2366-1 & olivacea & Brazil, SP, Capão Bonito, Parque Estadual de Intervales & Piper aduncum L. & K2387 \\
\hline K2369-1 & olivacea & Brazil, SP, Capão Bonito, Parque Estadual de Intervales & Piper aduncum L. & K2387 \\
\hline K2369-3 & olivacea & Brazil, SP, Capão Bonito, Parque Estadual de Intervales & Piper aduncum L. & K2387 \\
\hline M523-2 & olivacea & Brazil, RJ, Itatiaia, Parque Nacional de Itatiaia & Piper cernuum Vell. & K1925* \\
\hline LEPSM615 & olivacea & & & \\
\hline M527-4 & olivacea & Brazil, RJ, Itatiaia, Parque Nacional de Itatiaia & Piper cernuum Vell. & K1925* \\
\hline M572-2 & olivacea & Brazil, RJ, Itatiaia, Parque Nacional de Itatiaia & Piper cernuum Vell. & K1925* \\
\hline LEPSM618 & olivacea & & & \\
\hline M516-1 & olivacea & Brazil, RJ, Itatiaia, Parque Nacional de Itatiaia & Piper crassinervium Kunth. & K1954* \\
\hline K2423-2 & olivacea & Brazil, MS, Corumbá & Piper amalago L. & K2423 \\
\hline M544-1 & olivacea & Brazil, RJ, Itatiaia, Parque Nacional de Itatiaia & Piper crassinervium Kunth. & K1954* \\
\hline K2367-3 & olivacea & Brazil, SP, Capão Bonito, Parque Estadual de Intervales & Piper crassinervium Kunth. & K1954* \\
\hline
\end{tabular}




\begin{tabular}{|c|c|c|c|c|}
\hline K2372-10 & olivacea & Brazil, SP, Capão Bonito, Parque Estadual de Intervales & Piper crassinervium Kunth. & K1954* \\
\hline K2367-5 & olivacea & Brazil, SP, Capão Bonito, Parque Estadual de Intervales & Piper crassinervium Kunth. & K1954* \\
\hline K2322-2 & olivacea & Brazil, SP, Jundiaí, Reserva Biológica da Serra do Japi & Piper arboreumAubl. & K1953* \\
\hline K2372-6 & olivacea & Brazil, SP, Capão Bonito, Parque Estadual de Intervales & Piper crassinervium Kunth. & K1954* \\
\hline K2372-8 & olivacea & Brazil, SP, Capão Bonito, Parque Estadual de Intervales & Piper crassinervium Kunth. & K1954* \\
\hline \#862 & olivacea & Brazil, SP, Mogi-Guaçu, Reserva Biológica de Mogi-Guaçu & Piper crassinervium Kunth. & \\
\hline M551-2 & olivacea & Brazil, RJ, Itatiaia, Parque Nacional de Itatiaia & Piper crassinervium Kunth. & K1954* \\
\hline M548-1 & olivacea & Brazil, RJ, Itatiaia, Parque Nacional de Itatiaia & Piper crassinervium Kunth. & K1954* \\
\hline M626-1 & olivacea & Brazil, RJ, Itatiaia, Parque Nacional de Itatiaia & Piper crassinervium Kunth. & K1954* \\
\hline M593-1 & olivacea & Brazil, RJ, Itatiaia, Parque Nacional de Itatiaia & Piper cf. tectoniifolium Kunth. & K1958* \\
\hline K1228-2 & olivacea & Colombia, Bogota & Piper bogotense C. DC. & \\
\hline JQ424371.1 & pallidicosta & & & \\
\hline JQ424372.1 & pallidicosta & & & \\
\hline K1228-1 & pallidicosta & Colombia, Bogota & Piper bogotense C. DC. & \\
\hline JQ179873.1 & pallidicosta & & & \\
\hline JF859258.1 & pallidicosta & & & \\
\hline$J Q 424375.1$ & pallidicosta & & & \\
\hline GQ433544.1 & pallidicosta & & & \\
\hline KU381316.1 & pallidicosta & & & \\
\hline JQ179915.1 & pallidicosta & & & \\
\hline MG572804.1 & pallidicosta & & & \\
\hline JQ179875.1 & pallidicosta & & & \\
\hline JQ179870.1 & pallidicosta & & & \\
\hline KU381055.1 & pallidicosta & & & \\
\hline HQ576249.1 & pallidicosta & & & \\
\hline MG572805.1 & pallidicosta & & & \\
\hline JX150931.1 & pallidicosta & & & \\
\hline KU381753.1 & pallidicosta & & & \\
\hline JX150863.1 & pallidicosta & & & \\
\hline GQ433565 & pallidicosta & & & \\
\hline GQ433565.1 & pallidicosta & & & \\
\hline
\end{tabular}




\begin{tabular}{|c|c|c|c|c|}
\hline JQ179924.1 & pallidicosta & & & \\
\hline MG572814.1 & pallidicosta & & & \\
\hline JQ179903.1 & pallidicosta & & & \\
\hline JQ179880.1 & pallidicosta & & & \\
\hline GQ433564.1 & pallidicosta & & & \\
\hline JQ424379.1 & pallidicosta & & & \\
\hline JQ424374.1 & pallidicosta & & & \\
\hline M157-3 & pallidicosta & Brazil, RJ, Itatiaia, Parque Nacional de Itatiaia & Piper cf reitzii Yunck. & M157 \\
\hline LEPSM922 & pallidicosta & & & \\
\hline M156-5 & pallidicosta & Brazil, RJ, Itatiaia, Parque Nacional de Itatiaia & Piper cf reitzii Yunck. & M156 \\
\hline M155-12 & pallidicosta & Brazil, RJ, Itatiaia, Parque Nacional de Itatiaia & Piper cf reitzii Yunck. & M158 \\
\hline M155-3 & pallidicosta & Brazil, RJ, Itatiaia, Parque Nacional de Itatiaia & Piper cf reitzii Yunck. & M158 \\
\hline JQ179895.1 & pallidicosta & & & \\
\hline JQ179923.1 & pallidicosta & & & \\
\hline JQ179901.1 & pallidicosta & & & \\
\hline JQ179902.1 & pallidicosta & & & \\
\hline JQ179905.1 & pallidicosta & & & \\
\hline JQ179906.1 & pallidicosta & & & \\
\hline GQ433557.1 & pallidicosta & & & \\
\hline JQ179891.1 & pallidicosta & & & \\
\hline JQ179941.1 & pallidicosta & & & \\
\hline M594-1 & olivacea & Brazil, RJ, Itatiaia, Parque Nacional de Itatiaia & Piper cubataonum C DC. & K1951* \\
\hline M357-2 & olivacea & Brazil, SP, São Paulo, Parque Estadual do Pico do Jaraguá & Piper cubataonum C DC. & K1951* \\
\hline M595-1 & olivacea & Brazil, RJ, Itatiaia, Parque Nacional de Itatiaia & Piper cubataonum C DC. & K1951* \\
\hline M594-2 & olivacea & Brazil, RJ, Itatiaia, Parque Nacional de Itatiaia & Piper cubataonum C DC. & K1951* \\
\hline K2420-27 & russearia & Brazil, MS, Aquidauana & Piper sp 1 & $\mathrm{~K} 2420$ \\
\hline K2420-3 & russearia & Brazil, MS, Aquidauana & Piper sp 1 & $\mathrm{~K} 2420$ \\
\hline K2420-21 & russearia & Brazil, MS, Aquidauana & Piper sp 1 & $\mathrm{~K} 2420$ \\
\hline K2420-a & russearia & Brazil, MS, Aquidauana & Piper sp 1 & K2420 \\
\hline TMD2018\#4 & russearia & Brazil, AM, Manaus, Reserva Ducke & Piper erectipilum Yunck. & M1041 \\
\hline TMD2018\#5 & russearia & Brazil, AM, Manaus, Reserva Ducke & Piper erectipilum Yunck. & M1041 \\
\hline
\end{tabular}




\begin{tabular}{|l|l|l|l|l|} 
TMD2018\#6 & russearia & Brazil, AM, Manaus, Reserva Ducke & Piper erectipilum Yunck. & M1041 \\
\hline TMD2018\#9 & russearia & Brazil, AM, Manaus, Reserva Ducke & Piper erectipilum Yunck. & M1041 \\
\hline TMD2018\#12 & russearia & Brazil, AM, Manaus, Reserva Ducke & Piper erectipilum Yunck. & M1041 \\
\hline TMD2018\#20 & russearia & Brazil, AM, Manaus, Reserva Ducke & Piper erectipilum Yunck. & M1041 \\
\hline
\end{tabular}

